\title{
A Research on Market Status and Purchasing Decision Influencing Parameters for Electric Vehicles: Indian Context
}

\author{
Amrut P. Bhosale, Akash Gholap, S A Mastud, D G Bhosale
}

\begin{abstract}
In the prospect of transforming the transport sector to green mobility which is surely estranged from harmful tailpipe emissions and fuel price hike, vigorous efforts and aggressive steps has been taken by the Indian Government by promoting National Electric Mobility Mission Plan 2020 (NEMMP 2020) and schemes such as Faster Adoption and Manufacturing of Electric Vehicles (FAME I \& II). Before leaning towards a commercial aspect, the barriers for this budding technology which is at a nascent stage in India must be contemplated. This paper focuses on the potential barriers and possible remedies which researchers and manufacturers must cogitate about. In order to predict the complete penetration of E-vehicles in India and check its feasibility, a market survey along with public opinion is carried out in this paper. This market survey and public opinion will help E-vehicles to share a substantial part of the transport sector in the near future and overcome the social-economic barriers.
\end{abstract}

Keywords: Electric Vehicles, Market Study, Public Opinion Survey, NEMMP 2020, FAME.

\section{INTRODUCTION}

India, the seventh largest county in the world with a population of about 1.35 billion and anticipated to be 1.5 billion by 2030, ranks second largest in the world after China [1]. The huge population's transport means depends on the widespread network of the road around 45.72144 million kilometres which is also the second largest road network in the world [2,3]. The immense rise in vehicle number, of which, almost all still run on conventional fuels attributes to the huge population, industrialization in the past few decades and vast mesh of road across the country. Recently listed, India ranks fourth largest automobile market with a sale of more than 4 million units, including passenger and commercial vehicles [4]. To cater the growing transport needs, the total number of registered vehicles across India is 210023289 (210 Million) by 2016 [5]. The National Electric Mobility Mission Plan 2020 (NEMMP 2020) has forecasted the numbers (electric vehicles) for passenger vehicles, commercial vehicles and two-wheelers to be 10 million, 2.7 million and 34 million respectively by 2020 [6]. Eventually, the nation has witnessed a considerable rise in the number of registered vehicles; the fuel requirements have also gone high

Revised Version Manuscript Received on 10 September, 2019.

Amrut P. Bhosale, Department of Mechanical Engineering, Veermata Jijabai Technological Institute (VJTI), Mumbai, Maharashtra, India. (email: bhosaleamrut13@gmail.com)

Akash Gholap, Department of Mechanical Engineering, Veermata Jijabai Technological Institute (VJTI), Mumbai, Maharashtra, India.

S A Mastud, Department of Mechanical Engineering, Veermata Jijabai Technological Institute (VJTI), Mumbai, Maharashtra, India.

D G Bhosale, Department of Mechanical Engineering, Veermata Jijabai Technological Institute (VJTI), Mumbai, Maharashtra, India. as the government is in pursuit to fulfil the fuel requirements. The import volume of crude oil for India for the financial year 2018 is 220.43 million metric tons (MMT) alone and considering other products such as LPG, Naphtha, lube oil, Bitumen, the volume rises to 255.89 MMT [7]. Table 1 displays crude oil and other products imports for the last five financial years. Such an umpteen amount of imports have peaked the crude oil import bill from 112 billion dollars in FY 2014-15 to 125 billion dollars by the end of FY 2018 [8]. The sky-high oil prices associated with the heavy imports is one of the future energy security conundrums before India.

As Asia dominates the global $\mathrm{CO} 2$ emissions made from fuel combustion, India contributes a substantial part in it, ranking second in Asia after China [9, 10]. Although the contribution of $\mathrm{CO} 2$ emission by transport sector in India is $13 \%$, the value is still significant and the total value is expected to touch 2.62 billion tonnes by end of current fiscal year $[10,11]$. This may hinder the goal of limiting the global $\mathrm{CO} 2$ emissions and hence the global rise in temperature as stated in Paris Agreement and by IPCC (Inter-governmental Panel on Climate Change).

Table 1: Total Oil imports for last 5 years.

\begin{tabular}{|c|c|c|c|c|c|}
\hline Year & 2013-14 & $211+15$ & $2015-16$ & $5016-17$ & $2117-18$ \\
\hline Imrots 4 MDI & 200593 & 210.73 & 23230 & 25021 & 25559 \\
\hline
\end{tabular}

Engulfed with the wave of rising environmental concerns and stringent emission norms, heavy imports of fuel along with the consistent escalation of fuel prices and national energy security, the government has taken steps to cogitate about alternative remedies. Liquid petroleum gas (LPG), biofuels, compressed natural gas (CNG) can be looked as possible alternatives according to some researchers but to some extent [12]. Whereas in order to totally decarbonize the tailpipe emissions, the government of India along with various governments across the globe has taken the initiative to promote electric vehicles and adapt this new technology which is at a nascent stage in India [13,14]. Meanwhile, a lot of research across the globe debate about the complete replacement of IC engine vehicle fleet by electric vehicles, this budding mode of transport is at the verge of the hype cycle and the real picture will be clear in coming decades. 


\section{GOVERNMENT INITIATIVES PANORAMA}

The government of India has come with an ambitious target of deployment of all vehicle fleet into electric vehicles by 2030 , an ambition also reckoned by EV experts [15]. In 2013, the government launched National Electric Mobility mission plan 2020 (NEMMP 2020), anticipating the sale of hybrid and electric vehicle to 6-7 million by 2020 which attributes to a fuel saving of about 2.5 million tonnes. The key objectives of NEMMP are to revive National Energy Security and promote the growth of indigenous manufacturing capabilities. Under NEMMP, the government have announced various attractive schemes, incentives, policies, development of R\&D which promises to expedite the said target.

The government announced Faster Adoption and Manufacturing of Electric Vehicles (FAME) in 2015 under NEMMP to accelerate the electric vehicles market and ramp up the sales by providing incentives for all segments of electric vehicles [16]. The FAME scheme gave new impetus to demand creation, pilot projects, development of new technology and charging infrastructure. The initial announcement of FAME I scheme was for 2 years 2015-2017 which was extended to September 2018 and again up to March 2019 before launching of FAME phase II [17, 18]. The total funding allocated for FAME I is 579 crore and the year wise fund distribution and Utilization is given in table 2 $[19,20]$.

With the FAME II scheme is yet to be finalised, sources depict the initial fund allocation up to 8730 Crore [21].

The National Institute for Transforming India (NITI Aayog), the government's apex policy think tank has defined the various policies in order to promote green mobility. The reports by NITI in MOVE (Global Mobility Summit, 2018) have defined policies regarding charging infrastructure, increasing efficiency of the E-vehicles, standards for chargers, battery materials and new battery chemistry, focus on small and public vehicles, last mile connectivity and rural transport which will help to keep India's E-vehicle expedition in pace with the global scale. The NITI has also taken an effort to catapult the e-vehicle's market through "Make in India" Initiative [22].

\section{MARKET SUMMARY}

The electric vehicle's market is segmented in four categories as shown in Table 3: Out of the four market segments, 'vehicle type' is the most common segment which is frequently preferred for market study. The total number of vehicles sold under the FAME scheme is 266878 (including Two wheelers L1 \& L2 Category, Two wheelers max power not exceeding 250Watts, Three wheelers L5 category, four wheelers M1 category and buses). According to FAME India statistics, the number of incentives claimed is 266717 which consist of amount Rs. 320.70 Corers [16]. The detailed market share of various vehicle types in India is given in fig. 1 .

The Figure 1 depicts that the two-wheeler electric market is most dominant compared to other sectors and will be continuing to remain at the apex considering the economic capabilities of the majority of Indian public and other social-economic problems regarding buying a vehicle. The two-wheeler market is sub-categorised in 'battery type'sealed lead acid(SLAB) and Li-ion battery, 'voltage type'-36V, 48V, 60V, $72 \mathrm{~V}$ and 'product type'-Scoter, motorcycle of which, the scooter segment sales are more than $95 \%$ of the total product type category shares and $48 \mathrm{~V}$ type and SLAB type category are spearheading in their respective categories [23]. This shows the huge potential for E-two wheeler market in India, which is already the biggest conventional two-wheeler market with the sales of more than 19 million units by the end of FY 2018 [24].

Table 2: Fund Allocation and Utilization under FAME Phase I (2015-2019)

\begin{tabular}{|c|c|c|c|}
\hline & Finacialyez & Funder Allocitas & Fund Vurratcin \\
\hline$T$ & $5015=16$ & $\begin{array}{l}\text { R. . } 5 \text { ander (1081 Mutison } \\
\text { DSD) }\end{array}$ & 16.75 cotei \\
\hline 2 & $2016-17$ & Re 144 anes & R. 144 arotes \\
\hline & $2017-18$ & Ro. 165 atems & R. 165 crares \\
\hline i & $2018-19$ (Tal 30 -062018) & $\mathrm{Rs} 260$ antes & Rx.23 crires (Apprux) \\
\hline
\end{tabular}

Table 3: Electric Vehicles Market Segmented

\begin{tabular}{|c|c|c|c|}
\hline 8y Teclisebagy & By Power Saute. & By Vetexhe Type & By Panver Irain \\
\hline 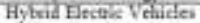 & sored Eiectiteity & Eectic Bicyedei & Senie Hybid \\
\hline $\begin{array}{c}\text { Puag is Eybrid Electic } \\
\text { Vethitis }\end{array}$ & $\begin{array}{l}\text { Ib-board dectric } \\
\text { Omenatas }\end{array}$ & Two Wheten & Patalled Hytist \\
\hline Butery Elnctic Veliciz: & & 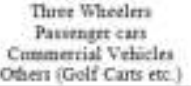 & Combianed fittrids \\
\hline
\end{tabular}

The scenario of the electric four wheeler market doesn't seem to be pleasing as the market falters for the FY year 2017-18 as compared to previous year, reported by Society of Manufacturers of Electric Vehicles (SMEV) [24,25]. At present Mahindra's 'E2O Plus' and 'e-Verito' are the only pure electric cars (BEVs) which are commercially available in India. Giants like Hyundai, Nissan along with Mahindra and Tata are likely to introduce more electric vehicles by the end of FY 2019-2020 [26]. Whereas, Toyota and Honda are the only companies which offer Hybrid Electric Vehicles (HEVs) in India. The Current sale under FAME India is 106176 Units which is nearly about $40 \%$ of total vehicle's sale under FAME scheme. Perhaps the global electric car market share for 2017 of India is below 1\% which is dominated by Norway (39\%), Iceland (11.7\%) and Sweden $(6.3 \%)$ [27].

India rolled out its first electric bus from Manali to Rohtang which is about $51 \mathrm{Km}$ in distance. The government of India is taking an aggressive stance to boost the introduction of electric buses in India [28]. The number of buses deployed under FAME scheme is very less and needs to be boosted by various state governments and Auto industries. The various initiatives have been taken by Tata Motors, Olectra-BYD to bring more number of electric buses to India roads [29-31]. Department of Heavy Industries (DHI), Ministry of Heavy Industries and Public Enterprises has sanctioned the funds for procurement of Electric buses with the target of deploying 10000 electric buses as issued by Ministry of Road Transport and Highways (MORTH) [32]. The details of the Procurement are given in Table 4. Figure 3 and 4 depict the 2 -wheeler and car market forecasted by 2025 respectively. 
Table 4: Sanctioned Projects by DHI under MORTH

\begin{tabular}{|c|c|c|c|}
\hline & Beaeficiary. & Delitering Afency & Sumber of Bwis \\
\hline 1 & \multirow{2}{*}{ 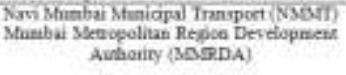 } & Vorion inda & S400 hobrid Cor thase \\
\hline 2 & & Tin ssotors & 25 Hyted City Buses \\
\hline 3 & BEST Mambai & $\begin{array}{l}\text { AV Manors and limpact } \\
\text { Antomotive Solatians } \\
\text { Limited }\end{array}$ & $\begin{array}{l}\text { Q- Renvfit so o Electris } \\
\text { Duser }\end{array}$ \\
\hline 4 & \multirow{2}{*}{ 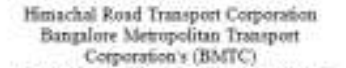 } & Sanctiomed by DAl & 25 full Electric Basen \\
\hline & & Proposal with Dan & 150 Electric Duses \\
\hline 6 & $\begin{array}{l}\text { The Hidco and Coul india Liminoel, west } \\
\text { Benpes }\end{array}$ & Eiche-KPIT & (PPP mode) \\
\hline
\end{tabular}

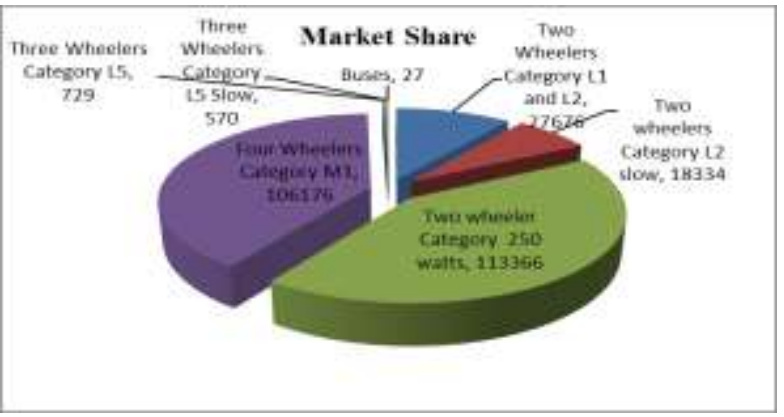

Figure 1: Category wise E-Vehicle's Market Share

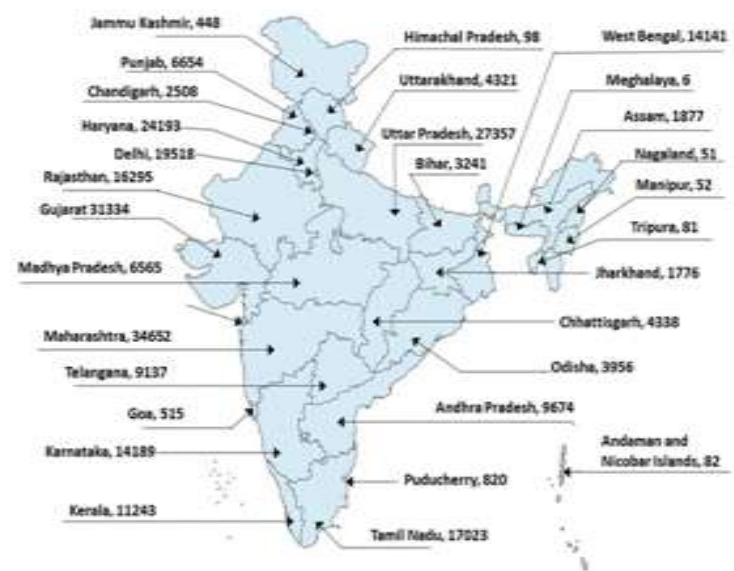

Figure 2: Geographic Distribution of E-Vehicle's Market

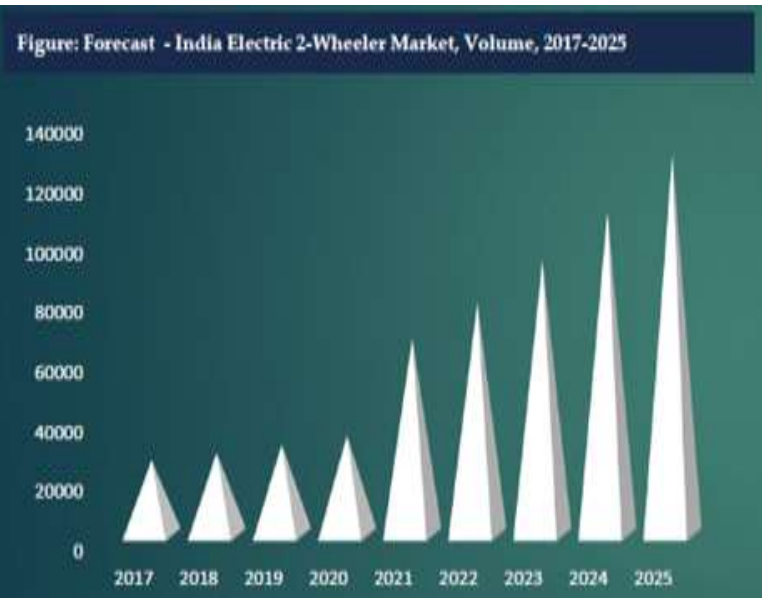

Figure 3: Forecasted sale of electric 2-wheeler market in India.[33]

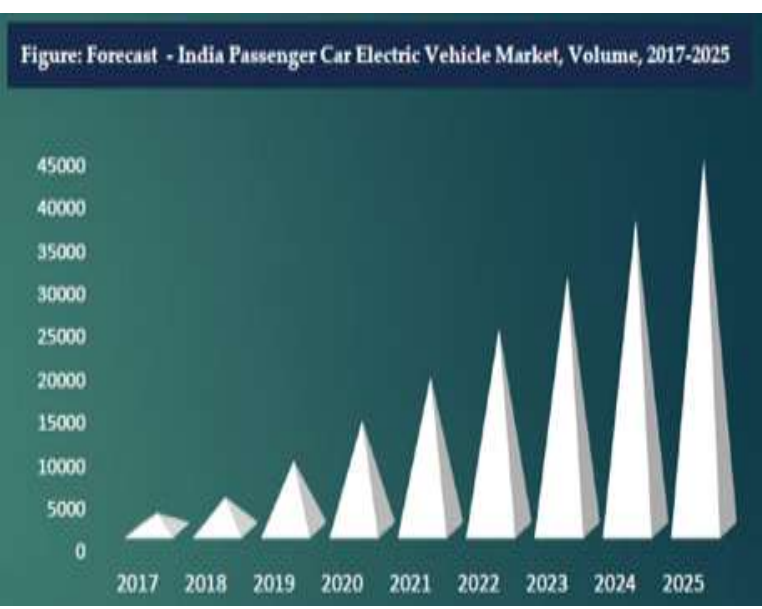

Figure 4: Forecasted sale of electric car market in India [33]

\section{RESULTS AND DISCUSSION OF PUBLIC OPINION SURVEY:}

\subsection{Need For Survey and Viability Gap:}

In spite of announcing various mission plans such as NEMMP 2020, schemes such as FAME I \& II, policies by NITI Aayog, joint efforts by various state governments in conjunction with professional bodies/societies such as SMEV, considerable progress have not been observed in the growth and penetration of electric vehicles in India. A country on one hand which has the fourth largest conventional vehicles market across the globe but on other hands rapid and enormous growth of electric vehicles is yet to be witnessed. The government recently resettled the ambitious goal of $100 \%$ electric vehicles by 2030 and came up scaling down to a realistic target of $30 \%$ of the total vehicle fleet. [34]. As the market and availability of other necessary ancillaries such as sufficient charging infrastructure are uncertain, most of the automobile companies are reluctant to introduce more E-vehicles models in the market, also the government is delaying to introduce more electric cars to the market, salvaging economic losses [35].

A public survey has been carried out to help predict the E-vehicle's feasibility, reasons for the delay in robust penetration of electric vehicles in India and to study the influencing factors affecting the purchasing decision by the Indian public. The purchasing decision-influencing factors are given in table 4

\subsection{Awareness and Interests:}

About $85 \%$ of the surveyed people travel less than 50 kilometres per day ( average to and fro distance about 100 $\mathrm{kms}$ ) which runs in favour of electric vehicles where the maximum distance per charge delivered by models available in India ranges from 110 to $130 \mathrm{Km} / \mathrm{charge}$. The awareness of the e-vehicles was studied primarily for such a vast country along with diverse geographic condition and with the unique urban-rural combination. It is observed that Battery Electric Vehicles (BEVs) and Hybrid Electric Vehicles (HEVs) have a credible awareness but attention towards the Plug-in Hybrid 


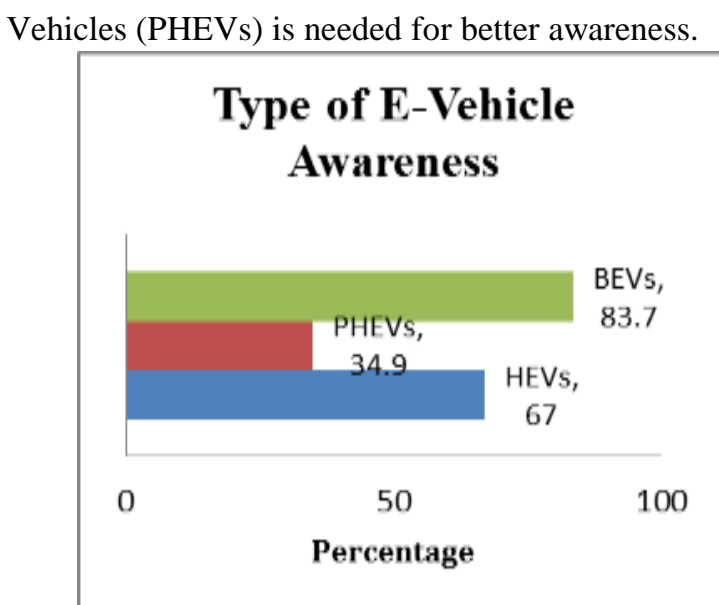

Figure 05: Type of E-Vehicle Awareness

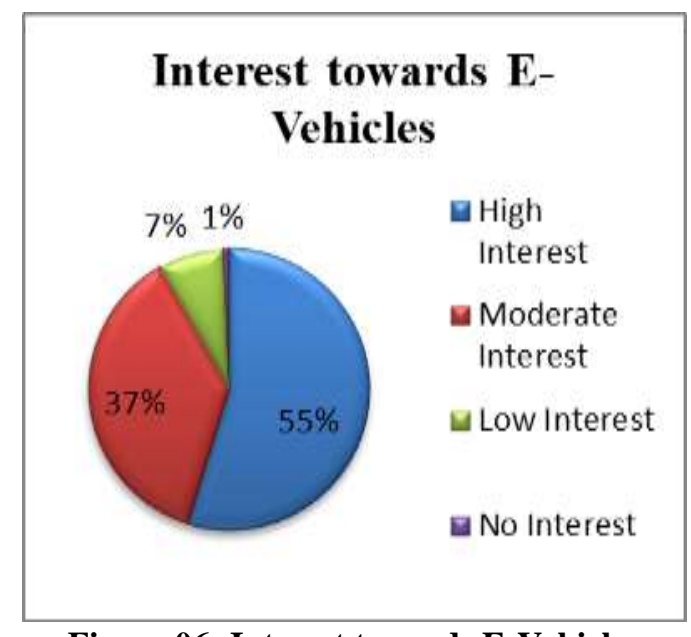

Figure 06: Interest towards E-Vehicles

Figure 5 and 6 shows the percentage of people having awareness about various electric vehicles and interest towards E-Vehicles respectively.

\subsection{Major Concerns:}

The biggest concerns about the electric vehicles, the survey showed the major concerns are: Availability of Charging Infrastructure, Battery power delivery range and high cost. Figure 7 shows the major concerns about e-vehicles in India. One of the biggest aspects hindering the penetration of e-vehicles in India is the lack of sufficient vehicle charging infrastructure. For comparison, a total number of petrol pumps in India is more than 60000 [36] whereas a total numbers of community charging Stations across India is 289 [37]. Currently the battery range offered by BEVs in India is $110-130 \mathrm{Kms}$ which is another concern observed by the survey is about the 'range anxiety', the BEVs might be fit for a distance of about $100 \mathrm{Kms}$ but the reliability of the BEVs for a travel range of about $150 \mathrm{Kms}$ or more needs to be addressed. For example, a journey from Mumbai to Pune where the distance is about 160 Kilometres needs a charging point a Lonavala (an approximate Mid-point, 83 $\mathrm{Kms}$ ). Hence, there is an insoluble dilemma about which concern (from charging infrastructure and battery range) should be given more emphasis to be developed first, leading to a classic chicken and egg syndrome.

The third aspect according to the survey is the high cost which is associated with high initial purchase cost, taxes, insurance and battery replacement after a particular age. For comparison, the approximate cost of a top variant of 'Maruti Alto 800 (VXI)' is 3.80 Lakh whereas considering a comparable electric vehicle, the base model of 'Mahindra e2O Plus' is 6.77 Lakh. The high cost is due to high battery costs which are also needed to be replaced after 5 years approximately, which further braces the high cost of E-vehicles. The battery (Li-ion) costs are anticipated to decline globally by 2025 [38] which further attributes to the reduction of E-vehicle's cost or unless some different battery chemistry is commercially introduced to BEVs. Figure 07 shows the Li-ion battery pack cost (USD/kWh) roadmap from 2010-2025.

Various studies about the economic competitiveness of electric vehicles with the conventional IC engine vehicles have been studied globally. A life cycle cost study done in China by Xin Zhao et al. [39] reveals that the life cycle cost of BEVs as compared to ICEVs is 1.4 times higher even after considering central government subsidies. A similar study made in Australia by Sami Kara et al. [40], shows that the performance of Nissan Leaf (a BEV) as compared to Toyota Corolla (an ICEV) performs worse on the platform of total life cycle cost (LCC). Also, a study carried by Y.S.Wong et al. [41] in Singapore explains that the EV is the most expensive car considering the LCC even under the government's Green Vehicle Rebate Scheme. An LCC analysis done by Makena Coffman et al. [42] for Hawaii reveals that EVs Cost more than selected comparable ICEVs considered for study which is based on a LCC model developed by Richard Raustad et al. [43]. The concerns related to safety and reliability in the survey perhaps seems to be less intense and it is believed to be mitigated as the technology advances.

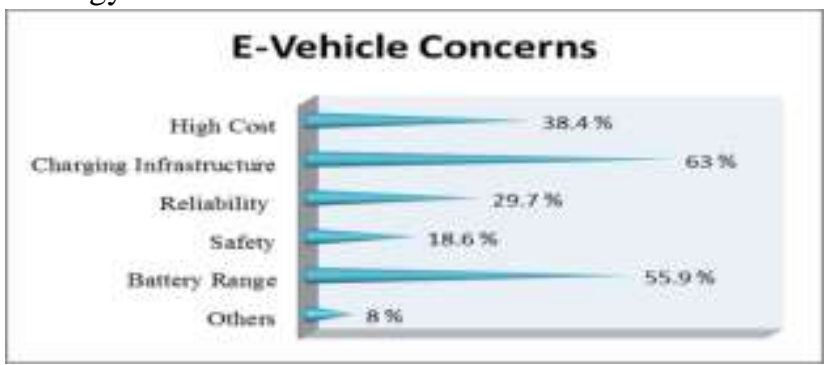

Figure 07: E-Vehicle major concerns.

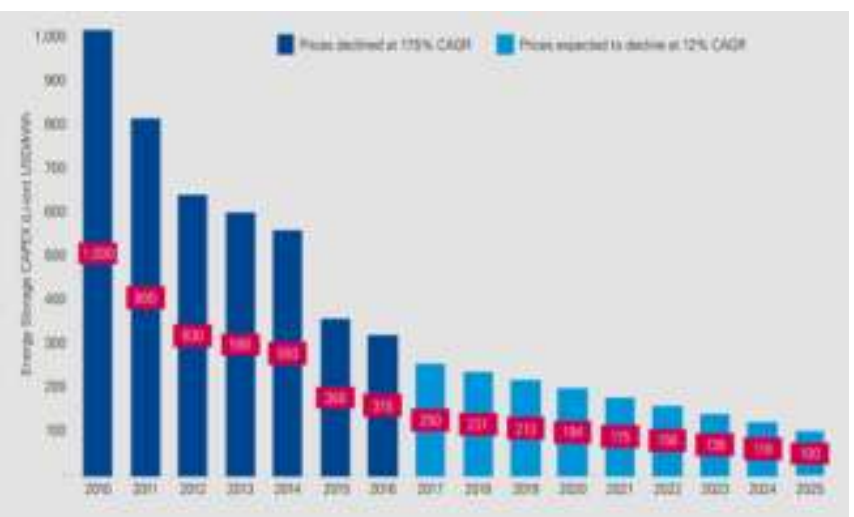

Figure 08: Li-ion battery pack roadmap 2010-2025 [38]. 


\subsection{Consumer Preferences and Fate of E-Vehicles:}

Figure 08 depicts the survey results regarding the fate of electric vehicles in India. Although the majority (52\%) of the people's views are E-vehicles will be a part of transport but not oust the ICEVs and about $42 \%$ think that e-vehicles will completely replace the conventional ICEVs. In a systematic study on this debate, Gautam Kalghatgi [44] states that the ICEVs will be a dominant transport mean at least by 2040 till E-vehicles technology completely matures and required infrastructure evolves. The E-vehicles will not be economically competitive with ICEVs and will need to wait till 2030 to share a substantial part in the transport sector [39, 45].

The consumer preference for the type of vehicle emphasis more on a four-wheeler, although a four-two wheeler or four-wheeler and moped vehicle combinations are also preferred by some consumers. According to the study, the most preferred charging point location is a residential area (79.9\%) followed by public charging stations (55.3\%) (Multiple preferences also preferred). People feel it convenient to charge the vehicle at home at night and travel at day time. As on-board and wireless charging technology are recently under study in full swing [46-48], this new mode of charging will definitely reduce the charging inconvenience and is in wish-list of about $82 \%$ of the consumers.

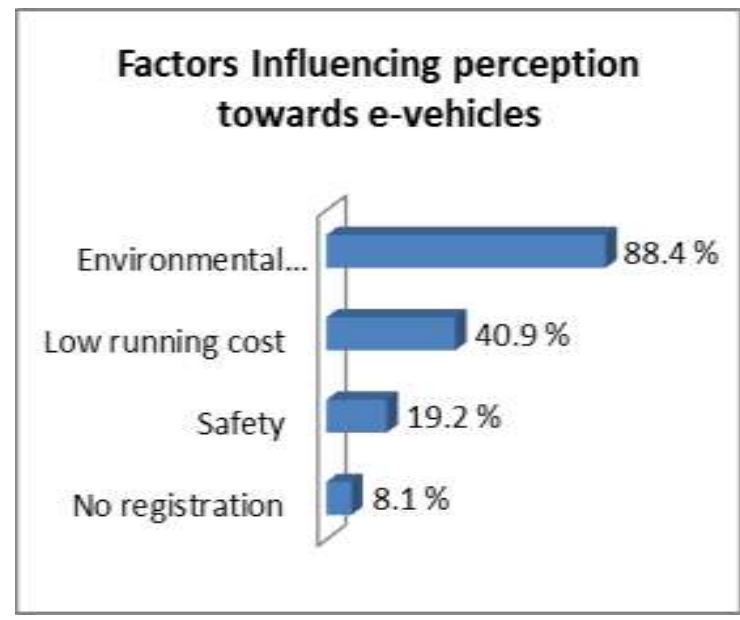

Figure 09: Factors Influencing perception towards E-Vehicles

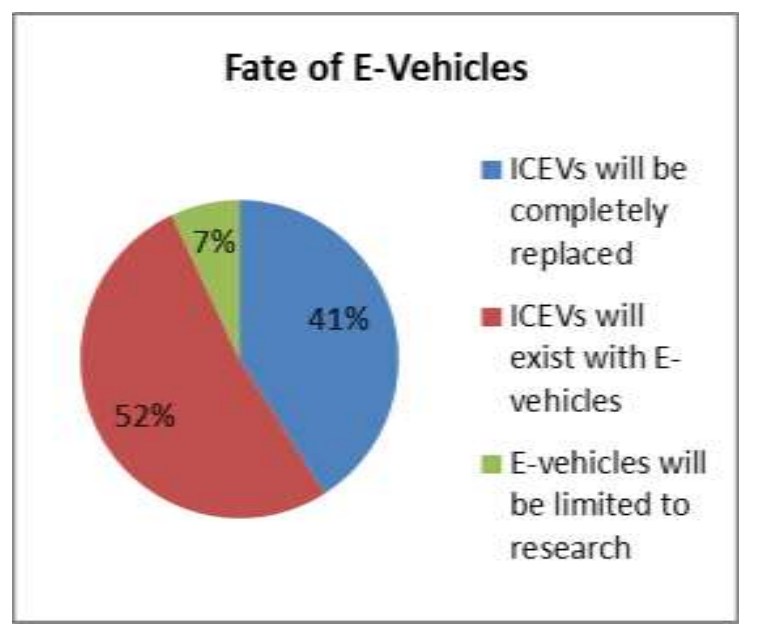

Figure 10: Survey view about fate of E-vehicles

\section{CONCLUSION}

The product/service sustainability in Indian market relies mostly on the consumer opinion even if other key hurdles are overcome. Although the sample size is representative of the entire population, the survey helps in understanding the primary concerns and will help to implement possible and/or alternative remedies. The actual population opinion might differ a bit due to huge geographical-social-economic diversity in India but this study will surely act as a nexus for advancing one step towards the penetration of electric vehicles in India.

The market study reveals that the E-Vehicles market is at a nascent stage but shows huge potential in near future. Especially the two wheel market is quite firm but more efforts will be needed to leapfrog the four wheeler market in India. As reckoned by many researchers, if the battery prices get declined over the years or if new affordable and reliable battery chemistry is introduced, the e-vehicles would be much affordable and eventually will boost the global e-vehicles market.

Initially, the e-vehicles were accepted in India with alacrity but raising concerns such as unavailability of credible charging infrastructure, range anxiety and high cost are making the consumers be reluctant in buying e-vehicles. The government is taking efforts to mitigate the major concerns by introducing NEMMP, FAME I \& II along with NITI Aayog which attributes to huge investments on building charging infrastructure or battery swapping stations, developing fast charging technology, introducing new policies, incentives and subsidy schemes and wavier of road taxes. Additional efforts must be made by conducting awareness camps and also arranging test drive workshops along with safety and environmental benefits to persuade e-vehicles benefits.

This budding technology is at the verge of the hype cycle and surely will have a substantial share in the mobility sector in the near future.

\section{REFERENCES}

1. India Population 2019 available at http://www.indiapopulation2019.in

2. Ministry of Road Transport and Highways, Government of India available at http://morth.nic.in/index 1 .asp?lang=1\&linkid=10\&lid=1 44

3. ROADS - Statistical Year Book India 2017, Ministry of Statistics and Programme Implementation, Government of India available at: http://www.mospi.gov.in/statistical-year-book-india/2017 $/ 190$

4. India pips Germany, ranks 4th largest auto market now (2018, March 24), The Economic Times. Retrieved from https://economictimes.indiatimes.com/industry/auto/india -pips-germany-ranks-4th-largest-auto-market-now/article show/63438236.cms

5. MOTOR VEHICLES - Statistical Year Book India 2017, Ministry of Statistical and Programme implementation, Government of India, available at http://mospi.nic.in/statistical-year-book-india/2017/189 
6. National Electric Mobility Mission Plan (NEMMP 2020), Department of Heavy Industry, Ministry of Heavy Industries \& Public Enterprise, Government of India available http://mospi.nic.in/statistical-year-book-india/2017/189

7. Petroleum Planning and Analysis Cell, Ministry of Petroleum and Natural Gas, Government of India available at https://www.ppac.gov.in/content/212_1_ImportExport.as $\mathrm{px}$

8. India's crude oil import bill to peak at record $\$ 125$ bn in current fiscal: Oil ministry (2018, October 22), The Economic Times. Retrieved from https://energy.economictimes.indiatimes.com/news/oil-a nd-gas/indias-crude-oil-import-bill-to-peak-at-record-125 -billion-in-current-fiscal-oil-ministry/66319124

9. CO2 emissions from fuel combustion overview (2018 edition), International Energy Agency available at http://www.indiaenvironmentportal.org.in/files/file/CO2 Emissions_from_Fuel_Combustion_2018_Overview.pdf

10. Report BROWN TO GREEN: THE G20 Transition to a Low-Carbon Economy 2018, INDIA country facts 2018 available

https://www.teriin.org/sites/default/files/2018-11/BROW N\%20TO\%20GREEN_2018.PDFFull Report available at http://www.climate-transparency.org/g20-climate-perfor mance/g20report2018

11. India drives global rise in $\mathrm{CO} 2$ emissions: Report (2018, December 6), The Indian Express Retrieved from https://indianexpress.com/article/india/india-drives-globa 1-rise-in-co2-emissions-report-5480529/.

12. SamvegSaxena, AnandGopal, AmolPhadke, Electrical consumption of two-, three- and four-wheel light-duty electric vehicles in India, Applied Energy (115) (2014) 582-590 (https://doi.org/10.1016/j.apenergy.2013.10.043)

13. The Central People's Government of the People's Republic of China, Energy saving and new energy automotive industry development plan, 2012, available at http://www.gov.cn/zwgk/2012-07/09/content_2179032.ht $\mathrm{m}$

14. Energy efficiency \& renewable energy, Vehicle Technology Office available at https://www.energy.gov/eere/vehicles/vehicle-technologi es-office

15. Indian Transport Sector Can Become All-Electric Driven by 2030 (2019, February 15) Retrieved from https://www.news18.com/news/auto/indian-transport-sec tor-can-become-all-electric-driven-by-2030-2037331.htm 1

16. FAME- India, National Automotive Board, Department of Heavy Industry, Government of India available at https://www.fame-india.gov.in/ (Last visited 10/03/2019)

17. Government extends FAME India scheme for third time (2018, September 30), The Economic Times available at https://economictimes.indiatimes.com/industry/auto/auto -news/government-extends-fame-india-scheme-for-thirdtime/articleshow/63759900.cms

18. Notifications (2018, September 27), Department of Heavy Industry, Ministry of Heavy Industries \& Public Enterprise, Government of India available at https://dhi.nic.in/writereaddata/UploadFile/NOTIFICATI ON\%2027\%20SEPT.PDF

19. FAME India Scheme- Notification, Department of Heavy Industry, Ministry of Heavy Industries \& Public Enterprise, Government of India available at https://dhi.nic.in/writereaddata/UploadFile/LS\%20No\%2 02255.pdf

20. Press Information Bureau, FAME India Scheme, Department of Heavy Industry, Ministry of Heavy Industries \& Public Enterprise, Government of India

available

at

http://pib.nic.in/newsite/PrintRelease.aspx?relid=186277

21. Government may extend financial support of Rs 8,730 crore in FAME II (2018, March 26), The Economic Times available

at https://economictimes.indiatimes.com/news/economy/fin ance/government-may-extend-financial-support-of-rs-87 30-crore-in-fame-ii/articleshow/63466878.cms?from =md $\mathrm{r}$

22. Zero Emission Vehicles (ZEVs): Towards a Policy Frame Work, MOVE- Global Mobility Summit, Report By NITI Aayog available

http://niti.gov.in/writereaddata/files/document_publicatio n/EV_report.pdf

23. Report on India Electric Scooters and Motorcycles Market Overview, Prescient \& Intelligence available at https://www.psmarketresearch.com/market-analysis/india -electric-scooter-and-motorcycle-market

24. India's electric vehicle goals being realised on two wheels, not four (2019, Jan. 14), The Economic Times. Retrieved from

https://economictimes.indiatimes.com/industry/auto/auto -news/focus-indias-electric-vehicle-goals-being-realisedon-two-wheels-not-four/articleshow/67522910.cms

25. Society of Manufacturers of Electric Vehicles, available at https://www.smev.in/ev-industry

26. Electric cars launching in India in 2019: New Mahindra and Tata Motors EVs to launch this year (2019, January 24) Financial Express Retrieved from https://www.financialexpress.com/auto/electric-vehicles/ electric-cars-launching-in-india-in-2019-new-mahindra-a nd-tata-motors-evs-to-debut-this-year/1453579/

27. Global EV Outlook 2018, International Energy Agency available at https://www.iea.org/gevo2018/

28. International Association of Public Transport (UITP)Indi https://india.uitp.org/articles/india-launched-electric-busservice

29. Tata Motors To Supply 255 Electric Buses In 6 Cities Across India (2019, January 31) Retrieved from https://auto.ndtv.com/news/tata-motors-to-supply-255-el ectric-buses-in-6-cities-across-india-1985756

30. Olectra-BYD delivers 40 buses to Telangana; Upbeat on demand, (2019, March 06), The Economic Times Retrieved from https://economictimes.indiatimes.com/industry/transporta tion/roadways/olectra-byd-delivers-40-buses-to-telangan a-upbeat-on-demand/articleshow/68282155.cms

31. All the Cities in India With Electric Bus Service Lucknow, Hyderabad, Sabarimala, Delhi and More (2019, $\begin{array}{llll}\text { February } & 12) & \text { Retrieved from }\end{array}$ https://www.news18.com/news/auto/hyderabad-telangan a-andhra-lucknow-sabarimala-delhi-all-the-cities-in-india -to-get-electric-bus-service-2033459.html

32. Electric Bus Market in India, International Association of Public Transport (UITP)- India available at https://india.uitp.org/articles/electric-bus-market-in-india

33. Indian Vehicle Market 2018-2025 Report, ANS MarketPro available http://www.ansmarketpro.com/report.php?id=5108

34. India scaling back electric vehicle ambitions (2018, March 18) available at https://asia.nikkei.com/Economy/India-starts-argument-o ver-realistic-EV-targets-for-2030 
35. India delays plan to roll out 10,000 electric cars to 2019 (2018, May 29), The Economic Times Retrieved from https://economictimes.indiatimes.com/india-delays-plan- $t$ o-roll-out-10000-electric-cars-to-2019/articleshow/64371 $111 . \mathrm{cms}$

36. More than 60,000 petrol pumps in India, $45 \%$ jump in 6 years (2017, November 29), The Times of India Retrieved from

https://timesofindia.indiatimes.com/business/india-busine ss/more-than-60000-petrol-pumps-in-india-45-jump-in-6 -years/articleshow/61848964.cms

37. Plug in India, Community Charging Stations available at http://www.pluginindia.com/charging.html

38. Report on Electric Vehicles- A case for a proactive approaches, ENRich 2017 (India) available at https://assets.kpmg/content/dam/kpmg/in/pdf/2017/11/El ectric-Vehicles.pdf

39. Xin Zhao, Otto C. Doering, Wallace E. Tyner, The Economic competitiveness and emissions of battery electric vehicles, Applied Energy (156) (2015) 666-675.

40. Sami Kara, Wen Li, Nikkita Sadjiva, Life Cycle Cost Analysis of Electric Vehicles in Australia, The 27th CIRP Conference on Life Cycle Engineering, (61) (2017) 767-772 ( doi: 10.1016/j.procir.2016.11.179)

41. Y.S.Wong, Wen-Feng Lu, Zizi Wang, Lifecycle Cost Analysis of Different Vehicle Technologies in Singapore, World Electric Vehicle Journal, Vol. 4, 2010.

42. Report on Electric Vehicle Lifecycle Cost Assessment for Hawaii, Electric Vehicle Transportation Centre available at http://evtc.fsec.ucf.edu/publications/documents/HNEI-07 -15.pdf

43. Report on Electric Vehicle Lifecycle Cost Assessment for Hawaii, Electric Vehicle Transportation Centre available at http://fsec.ucf.edu/en/publications/pdf/fsec-cr-2053-17.p df

44. Gautam Kalghatgi, Is it really the end of internal combustion engines and petroleum in transport?, Applied Energy, (225) (2018) 965-974.

45. M.A.Hannan, F.A.Azidin, A.Mohamed, Hybrid electric vehicles and their challenges: A review, Renewable and Sustainable Energy Reviews, (29) (2014) 135-150.

46. Chunting Chris Mi,Giuseppe Buja, Su Y. Choi, Chun T. Rim, Modern Advances in Wireless Power Transfer Systems for Roadway Powered Electric Vehicles, IEEE Transactions on Industrial Electronics, (2015) Vol. 63. (doi: 10.1109/TIE.2016.2574993).

47. Su Y. Choi, Beom W. Gu, Seog Y. Jeong, Chun T. Rim, Advances in Wireless Power Transfer Systems for Roadway-Powered Electric Vehicles, IEEE Journal of Emerging and Selected Topics in Power Electronics, Vol 3 2014. DOI: 10.1109/JESTPE.2014.2343674

48. A Ahmad, MS Alam, RC Chaban, Efficiency enhancement of wireless charging for electric vehicles through reduction of coil misalignment, IEEE Transportation Electrification Conference and Expo (ITEC), 2017 21-26. 